\title{
Sociogênese da mobilização étnica ocorrida na comunidade Serra do Truarú (Terra Indígena Serra da Moça, etnorregião Murupú, Boa Vista-RR)
}

Sociogenesis of ethnic mobilization occurring in the Serra Truarú community (Serra da Moça indigenous land, Murupú ethnoregion, Boa Vista-RR)

\author{
Eriki Aleixo Wapichana* \\ *Universidade Federal do Amazonas - Manaus, AM, Brasil \\ Doutorando em Antropologia Social \\ eriki.aleixo@hotmail.com \\ https://orcid.org/0000-0002-2658-3027
}




\title{
Resumo
}

O objetivo deste artigo é descrever a sociogênese de uma mobilização étnica ocorrida na comunidade indígena Serra do Truarú, iniciada em 2004. A referida mobilização tinha como objetivo precípuo a ampliação da Terra Indígena Serra da Moça, algo que já era demandado pelos Wapichana e Macuxi desde a demarcação no ano de 1991. Para este artigo, procuro etnografar os antecedentes da referida mobilização, tomando como elementos importantes formadores desse processo: as experiências das lideranças indígenas, a vivência de restrições cotidianas a partir de negociações fundiárias desfavoráveis e o contexto político regional. A conjugação desses fatores desencadeou mobilizações indígenas e, dessa forma, constata-se que tais elementos são fundamentais na orientação das formas organizativas e na politização da identidade étnica para atuarem na luta por suas terras tradicionalmente ocupadas.

Palavras-chave: mobilização étnica; experiência; lideranças; Lago da Praia.

\begin{abstract}
The objective of this article is to describe the sociogenesis of an ethnic mobilization that happened in the indigenous community Serra do Truarú, in 2004. This mobilization had as its main objective the expansion of the Serra da Moça Indigenous Land, something that has already been demanded by the Wapishana and Macuxi since the demarcation in 1991. For this article, I ethnograph the antecedents of the mentioned mobilization, taking as important elements forming this process: the experiences of indigenous leaders, the experience of daily restrictions based on unfavorable land negotiations and the regional political context. The combination of these factors triggered indigenous mobilizations and this way, it turns out that these elements are fundamental in the orientation of organizational forms and in the politicization of ethnic identity to act in the struggle for their traditionally occupied lands.
\end{abstract}

Keywords: ethnic mobilization; experiences; leadership; Lago da Praia. 


\section{Introdução}

O objetivo deste artigo é descrever a sociogênese de uma mobilização étnica. Tal mobilização ocorreu na comunidade Serra do Truarú ${ }^{1}$ e tinha como objetivo precípuo a ampliação da Terra Indígena Serra da Moça (ver mapas nas Figuras 3 e 4). Essa mobilização culminou na criação de uma nova comunidade no ano de 2004: a comunidade Lago da Praia, e que teve seu "fim" no ano de 2009. Embora tenhamos decidido retomar as terras apenas em 2004, quando de fato nós, indígenas da Serra do Truarú nos deslocamos para construir um barracão comunitário e as moradias, a discussão já tinha sido iniciada na década de 1990, após sua demarcação, quando as comunidades da Terra Indígena Serra da Moça ainda faziam parte da etnorregião ${ }^{2}$ Taiano. Antes de 2008, as comunidades pertencentes à etnorregião Murupú pertenciam ao Taiano (atualmente denominado Tabaio). Devido ao fato de o Centro Regional ficar muito distante e por causa das pautas mais específicas dessas comunidades, foi necessário a criação do Murupú, sendo reconhecida desde então pela Fundação Nacional do Índio (Funai) e pelo Conselho Indígena de Roraima (CIR), e passou a agrupar as terras indígenas Serra da Moça (comunidade Serra da Moça,

1 Truarú, na Terra Indígena Serra da Moça, é utilizado para nomear três coisas: a comunidade (comunidade Serra do Truarú), a serra (serra do Truarú) e o igarapé mais importante da comunidade (igarapé Truarú). Truarú em algumas versões vem de truaruary que significa "cobra-grande" e faz parte da cosmovisão dos Wapichana dessa comunidade. Outra versão conta que Truarú era um andarilho que vivia no "pé" da serra, como se fosse um vigia. O nome Truarú é tão importante não apenas por nomear as coisas, mas também porque muitas doenças que aconteceram no passado, epidemias que chegaram a matar muitas crianças, entre elas filhos e filhas de alguns ainda vivos, e o motivo era que a cobra-grande tinha acordado e começado a "pegar" as sombras das crianças e dos doentes, pois estavam mais frágeis. Este Truarú não pode ser confundido com a comunidade Truarú da Cabeceira da Terra Indígena Truarú, que apresenta uma outra narrativa de origem para o nome (ver na Figura 1 o esquema de divisão territorial da etnorregião Murupú para facilitar o entendimento).

2 A noção de etnorregião ou simplesmente região, é utilizada conforme a atribuição dos próprios agentes sociais para as organizações/divisões territoriais que obedecem a critérios específicos. Elas reúnem as comunidades de diferentes terras indígenas que compartilham um certo número de elementos culturais, relacionam-se entre si territorialmente e possuem articulações políticas em comum. As etnorregiões referidas são: Amajari, Baixo Cotingo, Murupú, Tabaio, Raposa, São Marcos, Serras, Serra da Lua, Surumú, WaiWai, Alto Cauamé e Yanomami. Essa organização serve de base para as organizações indígenas como também para os órgãos indigenistas (Funai, DSEIs) para implementar determinadas políticas públicas. 
comunidade Serra do Truarú, comunidade Morcego e comunidade Lago da Praia), Terra Indígena Truarú (comunidade Truarú da Cabeceira) e Terra Indígena Anzol (comunidade Anzol). ${ }^{3}$

Terra Indigena Truarú

Comunidade Truarú da Cabeceira

\section{Etnorregião Murupú}
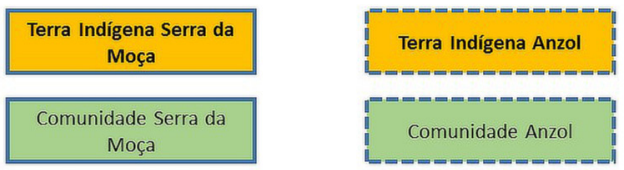

Comunidade Serra do Truarú

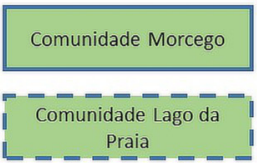

Figura 1. Divisão territorial da etnorregião Murupú. Fonte: elaborado por Eriki Aleixo Wapichana, 2020.

Partindo da abordagem de Bourgois $(1988,1989,1993,1994)$, procuro relacionar aspectos culturais e identitários a aspectos políticos e econômicos, uma vez que entendo que a interação entre esses aspectos pode se tornar a base das referidas mobilizações étnicas. Parto ainda de Almeida $(2008,2010)$, que buscou refletir sobre as mobilizações na região amazônica, nas quais indígenas e outros povos e comunidades tradicionais mobilizam suas identidades étnicas tornando-as identidades de lutas para atuarem politicamente nos contextos de conflitos sociais.

Ainda: proponho-me a historiografar os antecedentes dessa mobilização ocorrida na comunidade Serra do Truarú, realizando um cotejo das narrativas

3 Esta última passou a ser incluída desde 2013 como parte da etnorregião. 
contadas por algumas lideranças com as fontes escritas, de forma que possamos entender o que motivou o pedido de revisão da Terra Indígena Serra da Moça. Nesse sentido, não é minha intenção realizar uma descrição exata dos fatos. No entanto, existe a possibilidade de reflexão sobre esses mesmos fatos através das fontes, o que torna possível realizar um percurso sócio-histórico desses acontecimentos marcados por violências, usurpação de terras e relações conflituosas com fazendeiros dos arredores da referida terra indígena que ameaçam as territorialidades específicas desses povos.

As fontes, como mencionei, são, além dos documentos escritos, as narrativas orais, as vivências, as memórias pessoais e coletivas e o conversar do dia a dia. Por isso, é necessário analisá-las em contexto relacional, de forma que possibilite o entendimento do processo social de construção dos fatores, seja de ordem estrutural ou das relações dos agentes sociais envolvidos (Elias, 2011) que conjugados desencadearam a referida mobilização, de modo que se possa contemplar na análise a preocupação com a criatividade dos agentes sociais e com a multiplicidade de planos em que as ações sociais podem ser lidas e inseridas (Pacheco de Oliveira, 2016, p. 268).

Ressalto que o presente escrito é parte da minha vivência, uma vez que sou Wapichana, morador da Serra do Truarú, comunidade onde ocorreu a referida mobilização. Por isso, o resgate da memória, enquanto elemento reflexivo para descrição e análise da referida mobilização é em grande parte devido a minha participação. Para mim, escrever sobre minhas percepções, afetações e memórias naquele período não é só necessário, mas também importante, já que refletir em forma de texto sobre essas questões é reviver as histórias contadas pelos parentes. ${ }^{4}$ Nesse sentido, o método reflexivo (Bachelard, 2008; Bourdieu, 2002) tornou-se imprescindível para pôr em questionamento

4 O termo "parente" aqui é usado não como uma categoria relacionada aos estudos de parentesco, que se refere aos laços de consanguinidade ou afinidades, mas enquanto uma categoria política de tratamento entre mim, o pesquisador, e os Wapichana da Terra Indígena Serra da Moça, à qual pertenço. Embora faça parte do referido grupo étnico, e muitos dos que chamei de parentes (tio ou tia) fossem realmente parentes "de sangue", esse não foi um critério para utilização do termo, já que ele abrange muito mais pessoas quando utilizado nesse tipo de situação social. Existem maiores informações para utilização do termo nos estudos antropológicos sobre o movimento indígena e como ele foi histórica e politicamente sendo incorporado entre os indígenas do Brasil (ver Baniwa, 2011; Ortolan Matos, 1997, 2006). 
todas as minhas vivências, experiências e conhecimentos apriorísticos, pois a reflexividade nos permite pensar as experiências dentro de um panorama macro e relacional que dialoga com a realidade concreta de conflito, luta e mobilização.

A comunidade indígena Serra do Truarú faz parte da Terra Indígena Serra da Moça e está situada no município de Boa Vista, na etnorregião Murupú, a cerca de 60 quilômetros do centro urbano. É habitada por indígenas majoritariamente Wapichana, mas também por Macuxi e não indígenas, que se relacionam através de casamentos interétnicos, se caracterizando enquanto um território pluriétnico (Almeida et al., 2013). Essa comunidade torna-se referência neste trabalho devido ao meu pertencimento a ela, como também por ser a comunidade que iniciou as atividades da mobilização de retomada quando as primeiras famílias se deslocaram para morar na comunidade Lago da Praia.

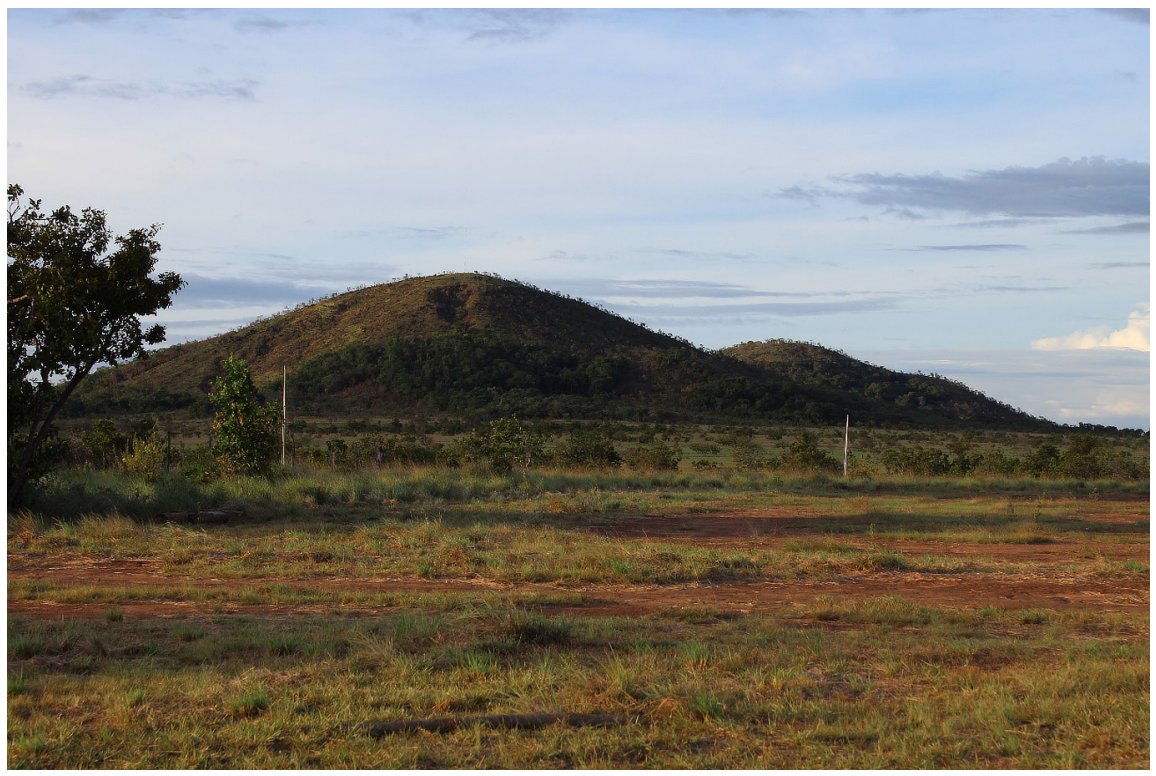

Figura 2. Serra do Truarú. Foto: Eriki Aleixo Wapichana, 2019. 
A Terra Indígena Serra da Moça, onde essas comunidades estão inseridas, é reconhecida legalmente desde 1991 como terra tradicionalmente ocupada (Brasil, 1991) e está localizada à margem esquerda do rio Uraricoera. Mesmo não tendo acesso ao referido rio, como tínhamos antigamente, é possível avistá-lo de cima da própria serra do Truarú na época da cheia dos rios. Essa terra indígena é configurada enquanto uma demarcação em ilha, ou seja, um pequeno pedaço de terra de 11.626,7912 hectares rodeada por fazendas, propriedades privadas (de empresários e políticos locais), grandes plantações de monocultura, principalmente acácia australiana (Acacia mangium) ${ }^{5}$ e mais recentemente pela monocultura da soja, e Projetos de Assentamentos Rurais. As terras indígenas demarcadas em ilhas se diferenciam daquelas de áreas contínuas que, por sua vez, são caracterizadas por serem grandes extensões territoriais, que abarcaram diversas comunidades e das quais foram retirados os indivíduos não indígenas que as tinham invadido. O caso mais emblemático é a Terra Indígena Raposa/Serra do Sol, em que os povos indígenas do estado de Roraima, através de intensa mobilização, encabeçada pelo CIR e diversos apoiadores, como entidades confessionais, intelectuais e pessoas engajadas em movimentos sociais e ambientalistas, conseguiram retirar os latifundiários plantadores de arroz e criadores de gado bovino de suas terras e, por conseguinte, demarcar 1.747.464,7832 hectares após mais de 40 anos de luta (Brasil, 2005).

5 O Projeto Nova Cartografia Social da Amazônia (PNCSA) em 2012 mapeou o conflito envolvendo indígenas da Terra Indígena Serra da Moça e a empresa Fit Manejo Florestal, que iniciou um plantio de Acacia mangium no início dos anos 2000. Através de oficinas realizadas nas comunidades, constatou-se que essa plantação tem ameaçado a sociobiodiversidade, a segurança alimentar e a própria reprodução física e cultural dos grupos indígenas. No ano de 2013 , a empresa FIT entrou com um pedido de despejo contra os indígenas, reivindicando a posse e retirada das pessoas da comunidade Anzol, comunidade essa que ficou de fora da demarcação no ano de 1991 e que atualmente vem reivindicando o reconhecimento legal de suas terras tradicionalmente ocupadas (Nova Cartografia Social da Amazônia, 2014). 


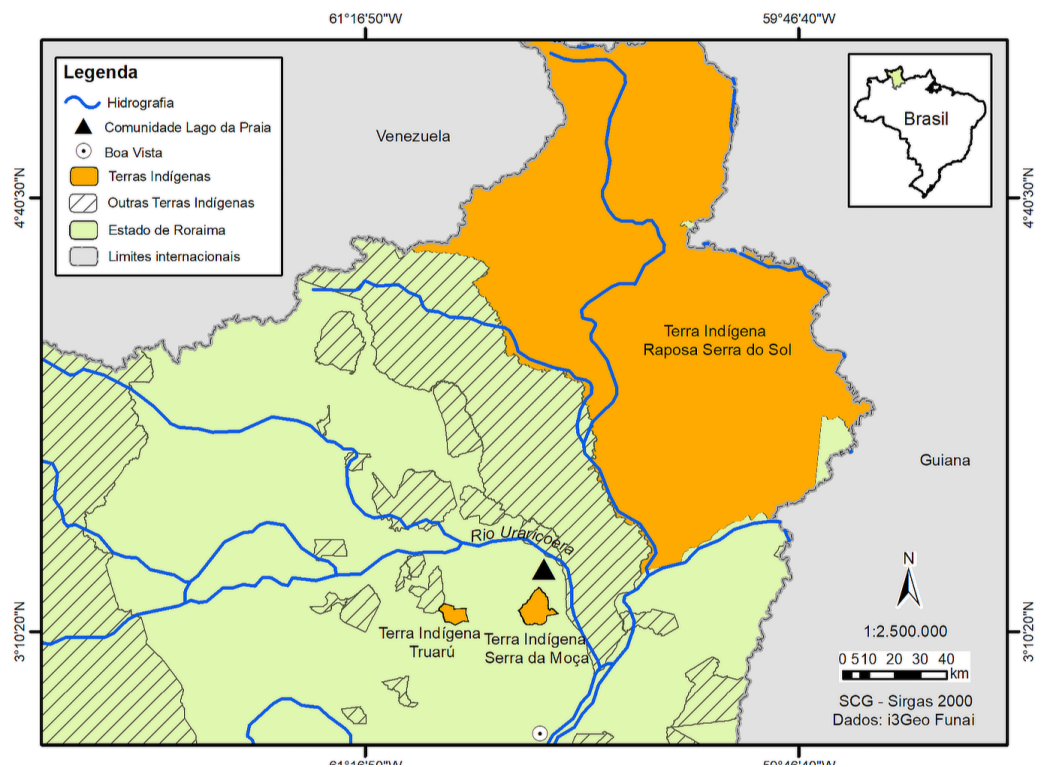

Figura 3. Localização da Terra Indígena Serra da Moça em relação à Terra Indígena Raposa/Serra do Sol. Fonte: elaborado por Mônica Côrtez, 2020.

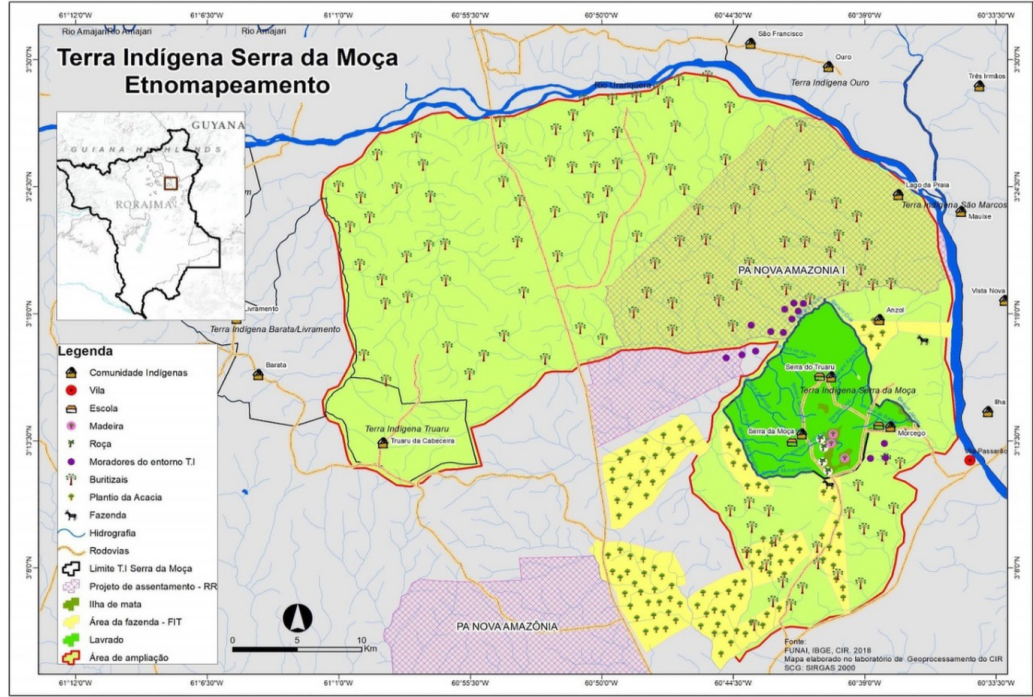

Figura 4. Etnomapeamento elaborado por indígenas das comunidades da Terra Indígena Serra da Moça, Truarú da Cabeceira e Anzol em oficinas realizadas pelo CIR para construção do plano de gestão territorial e ambiental.

Fonte: Conselho Indígena de Roraima ([s.d.]). 


\section{Considerações sobre mobilização étnica e política de identidade}

As mobilizações étnicas, para Bourgois (1988, 1989, 1993, 1994), podem ter como base, em seu processo de formação, uma interação dialética entre afiliações étnicas e culturais com fenômenos políticos e econômicos. Ao examinar os fenômenos de mobilizações étnicas ocorridas na costa caribenha da América Central em três diferentes povos e em diferentes momentos da história: o movimento de Marcus Garvey, entre os índios ocidentais que foram trabalhar nas plantações de banana por volta de 1910-1920; o movimento religioso em Mamachi entre os nativos americanos Guaymi do Panamá e a greve de 1960 na United Fruit Company; e a mobilização de indígenas Miskitu contra o governo da Nicarágua, no período 1982-1985, Bourgois afirma que as mobilizações étnico-políticas que cada um desses povos dinamizou, em diferentes contextos históricos, são sustentadas por uma dinâmica estrutural. No entanto, para além das estruturas, as referidas mobilizações nos esclarecem o que podemos entender por afiliação étnica. Mais genericamente, as mobilizações nos mostram como os fenômenos ideológicos interagem com a realidade material através de processos políticos e, ao analisarmos essas interações, avaliando o fator étnico, podemos concluir que sua relação dialética com a economia não está em posição de subordinação, isto é, fatores econômicos, culturais, étnicos, ideológicos interagem simétrica e dialeticamente entre si desencadeando tais fenômenos, bem como refletindo-se nas condições precárias de trabalho e nas hierarquias sociais.

É a partir dessas possiblidades analíticas que busco identificar fatores étnicos/identitários atrelados a elementos e experiências políticas que desencadearam uma autoconsciência, de forma que, para os indígenas, ter acesso aos lugares que haviam ficado de fora da demarcação da Terra Indígena Serra da Moça não era suficiente, sendo necessário garantir o seu usufruto por meio do aparato jurídico e administrativo respectivo.

As mobilizações também são encontradas nas discussões de Almeida (2010), mostrando-as em suas análises não apenas enquanto fenômenos sociais ou realidade empírica, mas também através de um viés teórico específico. $O$ autor afirma que as mobilizações sociais da região do rio Negro, na Amazônia, especialmente as indígenas, passaram a incorporar componentes identitários 
a diversas outras pautas econômicas, sociais, ecológicas e territoriais, fazendo com que fosse ampliada a diversidade das identidades coletivas. Em conjunto com o fator étnico, essas mobilizações ocorrem entrelaçadas à luta pelos direitos territoriais e recursos básicos para as sobrevivências físicas e culturais desses sujeitos. Tais reivindicações apresentam um potencial significativo, tornando possível a agregação de diversos elementos que podem proporcionar a articulação de outros como autoconsciência cultural com critérios ambientais, reforçando o conhecimento aprofundado dos ecossistemas e estimulando laços de solidariedade entre as comunidades locais pela politização de aspectos específicos que lhes são comuns (Almeida, 2010). Essas mobilizações apresentam um potencial transformador de suas realidades, conforme assinala esse autor. Assim, a afirmação das identidades indígenas é evidenciada conjuntamente com suas modalidades de resistência e suas práticas mais triviais para impedir o intrusamento em seus territórios ou para retomar os territórios usurpados.

A exemplo do que estou tratando, encontramos em outros trabalhos de pesquisadores indígenas, como Tuxá $(2017,2018)$, que tratou do conflito envolvendo seu povo, que teve parte do seu território inundado pela construção da Hidrelétrica de Itaparica ao fim da década de 1980, mobilizando posteriormente estratégias discursivas para efetivação de denúncia de violência; Terena (2019), que discute as estratégias de mobilização e organização das lideranças do seu povo Terena no processo de retomada de seus territórios, localizados no Mato Grosso do Sul; Benites (2014), do povo Guarani-Kaiowá, que tratou de estudar os processos políticos que mobilizaram seu povo para recuperar seus antigos territórios (tekoha), promovendo uma articulação das famílias indígenas por laços de solidariedade (ñomoiru ha pytyvõ) fortalecidos por seus líderes espirituais (ñanderu/oporaíva e ñandesy); já Macuxi (2017) buscou analisar a forma como a pauta da violência foi incorporada na agenda política do movimento de mulheres indígenas em Roraima, especialmente na Terra Indígena Raposa/Serra do Sol, que passaram a se articular em movimentos sociais e sistemas jurídicos do Estado brasileiro; Kokama (2016) analisou como seu povo buscou se reorganizar formando um movimento coletivo em prol da reafirmação da identidade, da reconquista, do território e da revitalização da língua; e, de igual modo, tenho tratado de entender o processo diferenciado de territorialização que envolveu os povos indígenas do estado de Roraima, em especial 
os Wapichana e os Macuxi da Terra Indígena Serra da Moça, que tiveram seus territórios impactados e cuja demarcação deixou de fora partes essenciais para sobrevivência física e cultural desses povos, e ainda como esses fatores desencadearem em mobilizações para retomar essas áreas (Melo, 2019).

Esses exemplos, mesmo que tratem de realidades distintas e geograficamente distantes, mostram unidades sociais mobilizadas em torno de uma identidade étnica, fundamentada na autoatribuição, mediante relações de contraste com outros grupos, como assinala Barth (2000). Essas identidades, que são reafirmadas e mobilizadas em contextos de conflitos para que se estabeleça uma unidade de ação política, são fatores decisivos no confronto e são objetivadas na interação com as agências e movimentos sociais e representativos (Santos, 2008).

A organização desses grupos étnicos, embora produto das relações sociais estabelecidas entre as diferentes unidades, marcada por "uma contínua dicotomização entre membros e não membros" (Barth, 2000, p. 33), é tratada por Pacheco de Oliveira (1998a, p. 269-295 apud Santos, 2008, p. 26) como insuficiente "para explicar a formação das unidades étnicas e a sua persistência, pois estas se objetivam no campo da política identitária, que é o motivo da manipulação dos fatores culturais".

O fator territorial é visto por Pacheco de Oliveira como dimensão estratégica do Estado-nação para incorporar essas unidades sociais etnicamente diferenciadas em seus "projetos" políticos. Assim, "administrar se refere à gestão territorial e a divisão de sua população em unidades geográficas menores e hierarquicamente relacionadas, definindo seus limites e demarcando suas fronteiras, remetendo, portanto, ao processo de territorialização" (Pacheco de Oliveira, 2016, p. 204).

O processo de territorialização, entendido como essa intervenção administrativa para dominar e reorganizar os povos indígenas, mesmo que parta do Estado, não pode ser visto como uma via de mão única, já que existe uma relação dialética, na qual não podemos negar uma agência efetiva dos grupos/ comunidades indígenas para construção de uma identidade étnica específica, de modo que se diferenciem de todo um conjunto generalizador de índios. Nisso, Pacheco de Oliveira (2016) reencontra Barth para refletir sobre as diferenças e as singularidades culturais como vetores organizacionais que são apropriados estrategicamente, como ferramentas de diferenciação (tanto ressemantizações 
quanto novas elaborações de tradição), transformando-as também em ferramentas políticas em contextos de mobilizações sociais.

Almeida (2008, p. 29), ao recuperar as noções de territorialização e territorialidade, nos traz uma nova abordagem, que se refere a "uma noção prática designada como 'territorialidade específica' para nomear as delimitações físicas de determinadas unidades sociais que compõem os meandros de territórios etnicamente configurados". A construção dessas delimitações territoriais "são as territorialidades que podem ser consideradas como resultantes de diferentes processos sociais de territorialização, que delimitam dinamicamente as terras de pertencimento coletivo que convergem para um território" (Almeida, 2008, p. 29). O autor considera que o critério político-organizativo sobressai, combinado com uma "política de identidades", da qual lançam mão os agentes sociais em seus movimentos para fazerem frente aos seus antagonistas e aos aparatos do Estado. A mobilização política, própria dos conflitos, tem produzido a identidade étnica de vários grupos, entre eles os grupos indígenas, que apresentam diferentes trajetórias, e acabam formando diferentes identidades coletivas com base em critérios diversos, a exemplo dos indígenas Tariano, Tukano, Baniwa, Baré, Arapaço, Werequena e Tuyuca da região de Barcelos (médio rio Negro), que mobilizam a categoria "piaçabeiro", tomando como critério a atividade de extração da piaçaba para fazerem frente às ações de empresários do turismo, sobretudo da pesca esportiva, e dos empresários da piaçaba, conhecidos na região como os "patrões exportadores" (Menezes, 2012, 2018, 2019).

Almeida ainda afirma que o processo de territorialização propicia instrumentos analíticos para compreender os territórios de pertencimento, e como eles vão sendo construídos politicamente através de mobilizações por livre acesso aos recursos naturais em diferentes regiões e em contextos históricos variados. Esse processo ainda é resultante de um conjunto de fatores, que envolve ainda a capacidade de organização e mobilização de suas identidades que vão expressar-se em diversos âmbitos no jogo do conflito, seja em documentos ou interferências públicas, retomadas, atos sociais, notas, entre outros meios de manifestação social.

As discussões aqui propostas são fundamentais para entender como a autodefinição pautada em fatores étnicos foi mobilizada pelos Wapichana e Macuxi da comunidade Serra do Truarú, consequentemente, da Terra Indígena Serra da Moça, para iniciar a retomada territorial que formou a comunidade Lago da 
Praia. $\mathrm{O}$ fato de se precisar daquele lugar para atender às necessidades básicas, tanto físicas quanto culturais, e o contexto de conflitos que estava se passando na Terra Indígena Raposa/Serra do Sol desde a década de 1990 até seu acirramento por volta de 2004 , ano que iniciou a retomada, foram conjugados para que houvesse essa outra mobilização: o fator étnico atrelado a um fator político e econômico foi fundamental para a organização das lideranças e para suas comunidades atuarem, transformando sua identidade étnica em identidade de luta.

\section{A experiência como um fator importante das mobilizações étnicas}

As diferentes experiências das lideranças fora da comunidade, em outras mobilizações e, principalmente, em situações relativas à prestação de serviços remunerados para os fazendeiros, proporcionaram uma compreensão mais crítica do tipo de relação historicamente estabelecida entre indígenas e não indígenas. Tais experiências propiciaram condições às lideranças para mobilizar suas comunidades para retomar terras que estavam nas mãos de fazendeiros, grileiros e outros usurpadores de seus direitos.

Por exemplo, o pajé Erasmo Ângelo, que foi tuxaua ${ }^{6}$ da comunidade Serra do Truarú na década de 1990, período em que estava se discutindo a pauta da Terra Indígena Raposa/Serra do Sol, assinou uma carta juntamente com outras lideranças mais emblemáticas do movimento indígena de Roraima, como o senhor Nelino Galé, Macuxi da etnorregião Baixo-Cotingo, que atuou fortemente naquele período; Jaci José de Souza, Macuxi da Terra Indígena Raposa/Serra do Sol,

6 Para todos os efeitos, o tuxaua é a liderança maior de uma comunidade indígena dessa região à qual estou me referindo. Entre os Ticuna, Pacheco de Oliveira (1988) afirma que tuxaua também pode vir a ser chamado de "capataz". Em termos de contraste, afirmo que não é o caso dos indígenas da Serra do Truarú. Os papéis e as funções dessas duas figuras são delimitadas: tuxaua atua muito mais no campo político, tanto "dentro" como "fora" da comunidade, enquanto o "capataz" é responsável por serviços marcados por trabalhos manuais, como, por exemplo, as atividades para "botar" uma roça ou construir uma cerca (nesses casos, o "capataz" é quem fica responsável por estar presente nesse trabalho, acompanhando e, principalmente, tomando frente das atividades). Contudo, as funções do "capataz" são limitadas mediante as decisões do tuxaua, que, em última instância, determina o que deve ser feito. O tuxaua é o cargo de maior representatividade, ou seja, é o responsável por representar as comunidades, seja nas relações interétnicas com os não indígenas, seja no próprio movimento indígena. 
que ocupou o cargo de coordenador do CIR no ano da demarcação em 2005 e que no ano de 1990 ocupava o cargo de vice-coordenador junto ao senhor Clóvis Ambrósio, da etnorregião Serra da Lua, que era então o coordenador-geral do CIR. A carta foi fruto de uma assembleia realizada na comunidade indígena Canta Galo, no dia 29 de outubro de 1990, encaminhada ao presidente da Funai, reivindicando a demarcação da Terra Indígena Raposa/Serra do Sol e da atual etnorregião Surumú, assim como a retirada de posseiros e garimpeiros de suas terras. A carta em si representa toda a demanda dos povos indígenas naquele período: a demarcação das terras indígenas em áreas únicas/áreas contínuas e a retirada das fazendas das suas terras. A carta que foi escrita a punho diz o seguinte:

Canta Galo, 29 de outubro de 1990.

Exmo. Sr. Presidente da FUNAI.

Nós lideranças indígenas, reunidas nos dias 28 e 29 de outubro de 1990, na aldeia Canta Galo, com participação de 88 Tuxauas e outras lideranças no total de 200 participantes, para discutirmos sobre a demarcação das nossas áreas indígenas, abaixo especificadas, assim requeremos:

1 - Área única

A área Raposa/Serra do Sol e Surumú com área aproximada de 1.347 .810 hectares, com 74 aldeias, com uma população de 9. 574. Nesta área estão situadas 154 fazendas de 122 proprietários. Dentro das referidas áreas também estão situadas 03 (três) vilas com aproximadamente 2.500 não-índios.

Todas as lideranças da área reivindicam a demarcação da área única Raposa/ Serra do Sol e Surumú.

Não tem tanta fazenda na área única. A maioria é posseiro sem documento. Tem gente com 5 cabeças de gado e já diz que é fazendeiro e quer indenização. Tem fazendeiro Jair que tem oito fazendas na área única e seu irmão Dandãe Alves dos Reis, que tem muita terra. E para que tanta terra na mão de uma única pessoa só, enquanto nossas comunidades indígenas não podem nem caçar, nem pescar e nem criar?

O fazendeiro reclama que é muita terra para os índios, e para que querem dar tanta terra para um só fazendeiro?

Queremos a área única. Tem dinheiro para tirar os garimpeiros das terras do Yanomamî e posseiros da área única também. 
Das áreas demarcadas, queremos que sejam retirados os posseiros que já foram indenizados e ainda não saíram e todos os outros garimpeiros, posseiros e invasores.

Das outras áreas delimitadas, queremos a demarcação, urgente.

Esperamos sermos atendidos.

Essa carta está anexada ao relatório de identificação da Terra Indígena Serra da Moça. Junto a ela, existem diversas outras com as mesmas reivindicações, de datas diferentes e de assembleias em outras comunidades. O conteúdo da carta é o mesmo: a demarcação de suas terras, a ampliação das que já tinham sido demarcadas em ilhas e a retirada dos invasores.

Esse tipo de trajetória das lideranças envolvendo o contato com diferentes contextos, agentes sociais e, principalmente, a troca de experiências com quem estava vivenciando a mesma situação de conflito é apontado por Ortolan Matos (1997) como um dos fatores responsáveis pelas lideranças compreenderem como funcionava a sociedade nacional. O contato proporcionava aos líderes indígenas o acesso a um determinado conhecimento sobre o "mundo dos não indígenas", o que foi e ainda é bastante útil para a mobilização e para as organizações indígenas defenderem seus direitos. Embora Ortolan Matos tenha direcionado sua pesquisa para entender o perfil das lideranças que atuavam no movimento indígena na Pan-Amazônia, como Ailton Krenak, Marcos Terena, Domingos Terena, todos esses que estiveram à frente do movimento indígena em âmbito nacional, na década de 1990, podemos pensar que esse tipo de trajetória mais localizada proporcionou também uma visão crítica e mobilizante das lideranças indígenas em Roraima.

A carta é apresentada aqui para mostrar que indígenas da Serra do Truarú também estavam em constante contato com as discussões sobre demarcação de terras e com as retóricas religiosas proferidas repetidamente nas assembleias indígenas. Vieira (2003) afirma que as assembleias indígenas em Roraima tiveram início a partir dos encontros organizados pela Igreja Católica, no início da década de 1960, bem antes do surgimento do Conselho Indigenista Missionário (Cimi). ${ }^{7}$ A Igreja passou a contribuir para organizar os indígenas politicamente,

7 O Conselho Indigenista Missionário foi criado pela CNBB apenas no ano de 1972, com o objetivo de atuar na defesa dos direitos e pela diversidade cultural dos povos indígenas. 
com o objetivo de conseguirem a demarcação definitiva de suas terras. Nesse período, surgiram os primeiros indícios de que estava começando um movimento indígena em Roraima, quando a Igreja promovia reuniões que contavam com a presença de indígenas de várias comunidades e diferentes grupos étnicos. Eles iniciaram as discussões nas assembleias e compartilhavam experiências de conflitos semelhantes como a invasão de suas terras, e passavam não apenas a xingar ou reclamar dos fazendeiros, mas a cobrar e criticar os órgãos públicos, como a Funai, pela postura adotada de favorecimento aos fazendeiros. $\mathrm{E}$, nesse momento, inicia-se um amadurecimento das organizações de várias etnias para reivindicar seus direitos e a demarcação de suas terras. O contato com o discurso religioso da denominada ala progressista já era frequente desde esse período e colocava em questão também as formas de tutela.

Embora os trabalhos sobre mobilizações indígenas ou movimento indígena tenham privilegiado as experiências de lideranças adquiridas "fora da comunidade", é importante ressaltar que a vivência cotidiana de conflito, do impedimento de ir caçar, pescar, criar e realizar certos rituais é também de igual importância e deve ser vista como fundamental para a compreensão das formas da luta e das mobilizações. Como, por exemplo, o risco de ir caçar à noite, o medo de ir e não voltar mais, devido a ameaças de tiros. Como ocorreu certa vez quando eu e meu tio Jackson Aleixo ${ }^{8}$ fomos pescar no igarapé do Muxinga, afluente do igarapé Truarú, que ficou de fora da demarcação. Quando já estávamos voltando de bicicleta, em meio a chuvas de mosquitos, carapanãs, eis que surge uma luz! Essa luz na verdade era a lanterna de alguém que vinha passando no lavrado no sentido contrário ao nosso. Logo quando vimos, nos jogamos no capim e nos escondemos até que a pessoa passasse. Assim que ela sumiu na noite, fomos embora para casa. No outro dia pela manhã, alguém chegou em casa dizendo que um dos capangas que tinha passado na noite anterior no caminho para o Muxinga, tinha ouvido vozes de pessoas, e que se ele as tivesse avistado, teria atirado de longe. Logo que ouvi isso, fiquei pensando que

8 O termo "tio" utilizado nesse caso tem a ver com laço consanguíneo, já que esse aqui chamado de tio é irmão da minha mãe. No entanto, na comunidade Serra do Truarú, os termos "tio" e "tia" são utilizados para além dos critérios consanguíneos, considerando ainda critério etário, isto é, pessoas mais velhas, que possuem idade de nossos avós e que são ou não do mesmo tronco familiar, também são chamadas de tios e tias, como se pode verificar na relação estabelecida entre mim e os demais interlocutores aqui apresentados. 
se não o tivéssemos avistado ou se ele nos tivesse avistado primeiro, nunca mais veríamos nossa casa e chegado com os peixes.

Lembro-me disso porque uma vez, quando esse meu tio tinha voltado do Lago da Praia, logo quando as famílias tinham efetivado a moradia, minha bisavó começou a gritar conosco: "Por que vocês tão brigando por terra? Essas terras os brancos já ganharam, são deles, não é mais nosso!" Meu tio respondeu: "Pra a gente não ter medo de caçar ou pescar. Aqui não tem mais, aqui não tem mais peixe nem capivara. Eu não vou morar lá, mas é de lá que eu tiro nosso sustento."

Esses diálogos e acontecimentos testemunhados ficaram fortemente marcados na minha memória, porque são experiências vividas e que fazem sentido e nos afetam (Favret-Saada, 2005) conforme a gente vivencia situações como essas. Delas, podemos entender diferentes motivações que levaram as pessoas a lutarem por pedaços de terras que são apenas pequenos fragmentos do que deveriam ser as terras originárias dos povos e comunidades tradicionais.

Como mencionei, o fator experiência é de fundamental importância para que ocorram as mobilizações. Bourgois (1993) toma esse fator para explicar a mobilização étnica entre os Guaymi na década de 1950, na província de Boca del Toro, no Panamá, que tinham deixado sua economia etnicamente diferenciada para trabalhar nas plantações da United Fruit Company, onde passaram a ocupar a camada mais baixa da hierarquia social devido a suas raízes étnicas. E, por isso, os Guaymi passaram a ocupar cargos de acordo com uma ideologia racista que pregava a ideia de que "eles tinham a pele mais grossa e não adoeciam" para que exercessem atividades altamente perigosas que eram as de espalhar os fertilizantes corrosivos e venenos nas plantações de bananas. Os trabalhos pesados e perigosos foram designados a eles, pois naquele contexto de hierarquias étnicas ser Guaymi representava ser humanamente inferior e incapaz de exercer qualquer atividade considerada mais complexa, como quando o autor perguntou aos administradores do porquê da segregação: eles disseram que os Guaymi não tinham qualidades intelectuais suficientes para ocuparem cargos mais especializados! Na verdade, essa ideologia racista era apenas uma desculpa para superexplorar os indígenas e aumentar os lucros das empresas, já que existiam 125 mil desempregados não indígenas nas cidades, mas eles não os empregavam, pois nenhum deles se submeteria às condições de exploração a que os Guaymi eram submetidos.

Os estigmas atribuídos aos Guaymi de ignorantes, fáceis de controlar, submissos à exploração eram reproduzidos constantemente pelos administradores 
para que assim eles não fossem obrigados a aumentar seus salários. E essa prática não era contestada pelos indígenas devido ao fato de eles não falarem o espanhol. A dominação simbólica e a exploração econômica são chamadas por Bourgois $(1988,1993)$ de opressão conjugada, ${ }^{9}$ o que quer dizer que não se trata da adição da dimensão simbólica à estrutura das relações de subordinação no trabalho e à marginalização econômica, mas sim de uma interação entre as mesmas, uma combinação. Trata-se ainda de pensar que a dominação étnica é parte intrínseca da exploração econômica, mas não se reduz a ela. A opressão conjugada manifestava-se em diversos âmbitos, tanto nos sistemas jurídicos, já que as punições que os indígenas sofriam eram piores do que as aplicadas aos não indígenas, como ainda nas relações de cunho sexual ou quando as práticas culturais dos Guaymi passaram a ser vistas como um espetáculo de degradação pública, pois estavam deslocadas do contexto em que elas expressariam um sentido político e simbólico.

Na década de 1960, os Guaymi se reuniram em torno de um líder carismático, mobilizando uma greve que durou três semanas. Eles se juntaram aos demais trabalhadores exigindo justiça, demitiram brutalmente os líderes que pregavam o statu quo da situação vivenciada e passaram a questionar a posição de poder dos chefes da companhia. Bourgois afirma que foram as experiências anteriores de 1910 que fez com que os Guaymi internalizassem o racismo, a opressão, possibilitando a explosão da referida greve. O ódio a si mesmo e àquilo que não era considerado tradição entre os indígenas fez com fossem liberadas as forças acumuladas ao longo de décadas, até séculos, de opressão e alienação (Bourgois, 1993, p. 61)

Corroborando a afirmativa de Bourgois, Almeida (2017, p.15) aponta que as atuações de lideranças indígenas, experientes de lutas cotidianas contra opressão do trabalho precário, como pode ser vista entre os Guaymi e a empresa United Fruit Company e entre os Wapichana e Macuxi na relação de acordos

9 Bourgois $(1988,1989)$ utiliza a expressão conjugated oppression na versão inglesa. Na língua francesa ela foi traduzida como oppression combinée (Bourgois, 1993) e na língua espanhola como opresión conjugada (Bourgois, 1994). Dessa forma, preferi utilizar a expressão "opressão conjugada" na língua portuguesa, por considerá-la a que mais se aproxima das outras traduções. Na língua Wapichana, a tradução mais aproximável seria pataka’ytan, que poderia significar "opressão", ou dikeyd kidia'u aimeakan, que, a grosso modo, traduz a noção de "maldade que alguém vem a sofrer" (expressões na língua Wapichana discutidas e elaboradas com a professora e pesquisadora Jama Wapichana). 
desfavoráveis e serviços prestados aos fazendeiros, convergiram para que se construíssem tipos de organizações pluriétnicas, associando pautas econômicas e lutas identitárias, e até mesmo propondo o rompimento com as formas de atuação no campo político, ou melhor, rompendo com as formas de tutela, institucionalizada e praticada pelo Estado.

\section{Antecedentes da mobilização: relações entre indígenas e fazendeiros}

O exemplo dos Guaymi no fornece elementos importantes para entendermos como a experiência é um fator mobilizante. Por exemplo, o tuxaua Jairo Pereira da Silva, ${ }^{10}$ que fora uma grande liderança, não só da comunidade Lago da Praia, mas do estado de Roraima, quando jovem, passou um tempo trabalhando nas fazendas de gado bovino localizadas nos arredores da comunidade; quando foi demitido, isso fez com que refletisse sobre a posse da terra e passasse a questionar a posição dos fazendeiros. Jairo Pereira da Silva faleceu em janeiro de 2017 em acidente de moto na BR 174, mas foi uma grande liderança que lutou pela demarcação da comunidade Lago da Praia, participou ativamente das mobilizações pela demarcação da Terra Indígena Raposa/Serra do Sol, chegou a ser vice-coordenador do CIR no ano de 2007. Tia Gercina fala dessa experiência do tuxaua Jairo quando perguntei como fora inicialmente discutida a ampliação da terra indígena: ${ }^{11}$

Eriki: E, assim, como foi para decidir para ir para lá, quem é que foi, quem tomou partido, e começou essa ideia de "vamos ocupar Lago da Praia", como é que surgiu essa ideia?

Tia Gercina: Essa ideia foi do irmão Jairo, foi do Jairo, porque ele disse que, sempre ele, né, não é conformado com esse, aonde ele mora, né, no Morcego, é muito pequeno para esse ficar trabalhando lá. É muito pequeno mesmo. Aí ele

10 Aproveito estas linhas para homenageá-lo e agradecer por ter sido um grande líder do movimento indígena do estado de Roraima.

11 Entrevista com Gercina Ângelo da Silva, Wapichana, moradora da comunidade Serra do Truarú. Serra do Truarú, etnorregião Murupú, Município de Boa Vista. Abril de 2016. 
disse que não queria morar aqui não, aqui no Truarú, ele disse: "Eu vou ter que morar num lugar mais assim que tem, que seja mais à vontade", né, aí ele disse, porque aqui ninguém pode mais morar assim vontade, aí não tinha pesca, não tinha caça, aqui não tem, né, tu sabe que aqui não tem caça, ninguém tem pesca, caçar à vontade. E lá no rio, assim no rio a gente pode pescar, né, pode pescar à vontade, se tem tempo para pescar, pesca mesmo, que é o rio grande. Ele trabalhava também, nessa fazenda, né, ele também trabalhava lá, ele trabalhou, ele trabalhou até quando terminou mesmo, que o homem parou, diz que ele estava devendo e entregou, diz que ele entregou, para o Bamerindus, que nesse tempo era esse banco, ele entregou na conta que ele estava devendo. Aí depois não sei o que aconteceu, que essa terra ficou parada, não tinha ninguém não, aí ele disse: "Agora tá bom de nós ampliar essa terra, nós vamos ampliar?" Nós falávamos de ampliar. Falava de ampliar. Só que ia ampliar mesmo, mas por causa da Raposa Serra do Sol, que, quando saiu a homologação, não ampliaram, e não teve mais oportunidade para ampliar, que era fechar mesmo.

Diversas lideranças chegaram a trabalhar com os fazendeiros, como vaqueiros das fazendas bovinas localizadas nos arredores das terras indígenas. À medida que iam sendo demitidos e voltando para suas comunidades, chegavam a se questionar o porquê de eles trabalharem para fazendeiros, e do porquê de serem mandados embora das fazendas que um dia foram morada de seus parentes e até suas.

Como demonstra a fala do tio Assis, que conta que os fazendeiros ofereciam empregos para os indígenas, depois de terem feito um "acordo". ${ }^{2}$ Após o "acordo", implantavam as fazendas, seus gados, com os trabalhos dos próprios indígenas, e, depois de um tempo, eles eram demitidos. Quando demitidos, os indígenas ficavam se questionando sobre trabalhar nas terras que eram suas, mas não poderem usufruir do seu trabalho, ficando alienados de toda produção. Em troca também do empréstimo da terra e da força do trabalho, os fazendeiros cediam seus tratores para prepararem a terra para plantação nas comunidades. Nas fazendas, iam trabalhar muitos homens.

12 Entrevista com Francisco de Assis Aleixo Ângelo, Wapichana, morador da comunidade Serra do Truarú. Serra do Truarú, região Murupú, Município de Boa Vista. Abril de 2016. 
Tio Assis: É, lá era área indígena. E aí aproveitou do tuxaua, ajudou tuxaua, ajudava como? Dava área mecanizada, aradada, né, para trabalhar. Então foi assim que ele fez com tuxaua, né. E arrumou emprego para nós aqui. E foram mesmo, foi Nazário, foi Moacir, foi Jairo, foi Antônio, quem foi mais? Eu sei que foi muita gente daqui. Adeilton, quem foi mais? Da Serra da Moça, foi Mauri, que já morreu. Eu sei que era gente da lavra daqui, sabe, meus irmãos também, Caci, Jaci, foram tudo para lá trabalhar, mas que vieram da Barata.

Especificamente nessa terra é que foi feito um tal "acordo" com um fazendeiro que se chamava Bixara, ocorrido entre as décadas de 1960 e 1970. Esse "acordo" foi feito com algumas lideranças atuantes desse período. $\mathrm{O}$ "acordo" funcionaria da seguinte forma: Bixara "acertava" com o tuxaua que ele utilizaria a terra por um período para aumentar seu gado bovino, implantar uma estrutura de fazenda, como curral, cerca, sede da fazenda (casa). Em troca do uso, seria dado emprego para indígenas, que trabalhariam para ele plantando capim, construindo as cercas, tomando conta do gado, campeando o gado, entre outras atividades. $\mathrm{O}$ fazendeiro também disponibilizaria seus tratores para preparar as terras nas comunidades, isto é, as terras próximas das casas dos indígenas seriam preparadas para que estes trabalhassem como agricultores. Depois de um tempo, quando aumentasse o gado, o fazendeiro devolveria as terras para os indígenas e os indígenas tornavam a morar nelas.

Embora tal prática tenha sido feita por vários fazendeiros, Bixara é um nome que aparece em todas as entrevistas para ilustrar esse "acordo" que foi feito com os tuxauas desse período, embora as pessoas não saibam o nome verdadeiro dele.

De acordo ainda com Vieira (2003), "acordos" como esse eram uma maneira de resolver problemas que envolviam indígenas e fazendeiros. Os fazendeiros estavam acostumados a lidar com os problemas das comunidades indígenas de três formas: "por meio da cooptação de suas lideranças, da força, que na maior parte das vezes terminava com a eliminação dos índios e posterior tomada das suas terras e com acordos, que sempre beneficiavam os fazendeiros, tendo como árbitro o administrador do órgão indigenista local do SPI ou da FUNAI" (Vieira, 2003, p. 168-169).

Durante a pesquisa não foi encontrado nenhum registro da intervenção da Funai no "acordo" com as lideranças da Serra do Truarú ou das outras 
comunidades da Terra Indígena Serra da Moça, mas, a partir da descrição das lideranças e de indígenas que ouviram de seus avós como ocorreu tal "acordo", pode-se dizer que se tratava de uma prática muito comum desse período, e foi o que ocorreu na comunidade Serra do Truarú com as áreas que posteriormente foram reivindicadas.

Depois de utilizar a terra para aumentar seu gado, o referido acordo previa que o fazendeiro a devolvesse para os indígenas. No entanto, após demitirem indígenas que foram trabalhar nas fazendas e, finalmente, terem implantado a fazenda com o rebanho bovino, nunca mais ocorreu essa devolução. E durante todo tempo em que os indígenas trabalhavam nas fazendas, os fazendeiros tentavam constantemente convencer as lideranças de que era melhor para eles que não se preocupassem mais com a terra que eles tinham "emprestado", pois seria muito melhor se eles trabalhassem nas terras aradadas. Como conta novamente tio Assis:

[...] porque ele disse assim pra mim, tuxaua, eu vou te dar um conselho, eu vou ajudar a dar arado pro senhor, é pro senhor plantar, é pra evitar de caçar, agora, porque se eu trabalho de dia, é melhor que caçar de noite, o senhor vai andar por aí, o senhor não sabe o que tem pela frente, acho que isso é. Aí ele ajudou mesmo né, mas até dando arado aí.

Bixara tentava convencer os indígenas de que trabalhar nas terras que ele aradaria era melhor do que ir caçar e pescar à noite, porque não teria nenhum perigo. Dessa forma, além de passarem a trabalhar apenas num espaço delimitado desenvolvendo atividades de agricultura, passariam a não se preocupar com as terras que o fazendeiro utilizaria para seu gado. Trabalhando nessas áreas mecanizadas, na visão de Bixara, os indígenas passariam a ter alguma utilidade econômica, já que caçar e pescar não eram atividades que geravam lucro e não eram suficientes para o sustento do próprio indígena. Bixara também tinha a ideia de que os indígenas, se estivessem trabalhando num espaço fixo, deixariam de ir caçar e pescar nas terras que estavam sendo utilizadas para reprodução do seu gado bovino, embora o acordo previsse que ele não impediria os indígenas de caçar e pescar por aquelas bandas.

Tio Assis conta o seguinte: 
Aí prometeu isso para o tuxaua, que a gente queria bem. E foi bom mesmo, qualquer coisa que a gente precisasse, óleo, se precisasse, tinha trator, aí prometeu ajudar de toda forma, todo ano ele fazia arado aqui para o tuxaua. O acordo foi assim. Só não impedia de caçar para lá, podia caçar para lá. Mas aí, ele já estava achando ruim também, né.

"Achando ruim" queria dizer que, após o fazendeiro tomar posse da terra, ele não queria mais que os indígenas da Serra do Truarú fossem caçar e pescar na própria terra, nos próprios rios, nos próprios igarapés; já estava descumprindo o acordo. E, assim, fazer com que trabalhassem sob uma outra lógica econômica, isto é, de se trabalhar apenas num local fixo, fora das terras de que Bixara tinha tomado posse, faria com que eles deixassem a terra para o fazendeiro, e posteriormente se esqueceria que um dia aquelas terras eram territórios indígenas.

Esse desconhecimento sobre as práticas culturais de caçar e pescar enquanto atividade produtiva é semelhante à ideia de que indígenas deveriam trabalhar em arados, lavouras, dentro de uma lógica de produção neoliberal de integração à sociedade nacional. ${ }^{13}$ Ainda hoje, existe uma preocupação em saber como ocorreu esse "acordo" que foi feito com tuxauas já falecidos, como demostrado numa fala da Geovânia quando perguntei se ela sabia o nome de registro desse Bixara, já que eventualmente isso era perguntado para fins judiciais. ${ }^{14}$

Após contar sobre esse tal "acordo" feito entre os tuxauas e o fazendeiro, tio Assis diz que tinha ficado surpreso ao receber a notícia de que a terra em que Bixara tinha sua fazenda não iria mais voltar para a comunidade, pois Bixara já

13 Esse tipo de pensamento colonizador sobre os povos indígenas foi prática utilizada para sua assimilação, oficialmente, até a promulgação da Constituição Federal em 1988. Anterior à CF, a política adotada para lidar com os povos indígenas era orientada pela lei n. 6.001, de 19 de dezembro de 1973 (Brasil, 1973), que tinha como premissa básica a integração dos povos indígenas à sociedade nacional. Embora esse discurso tenha chegado ao fim com o reconhecimento da autonomia dos povos indígenas, "o respeito às suas organizações sociais, costumes, línguas, crenças e tradições, e os direitos originários sobre as terras tradicionalmente ocupadas", pronunciamentos como "os nativos são seres humanos exatamente como nós" e "as ONGs querem manter os índios como verdadeiros homens das cavernas" ainda fazem parte das falas oficiosas da política neoliberal e autoritária brasileira. Observamos que a visão de Bixara nesse período estudado é orientada por essa ideologia integracionista e autoritária.

14 Entrevista com Geovânia Ângelo Aleixo, Wapichana, moradora da comunidade Serra do Truarú. Serra do Truarú, região Murupú, Município de Boa Vista. Abril de 2016. 
tinha passado as terras para seu nome e, após demitir todos os trabalhadores indígenas, as tinha vendido para o banco Bamerindus:

Tio Assis: [...] Assim foi esse acordo, aí, tuxaua saiu já, né, que era Zé Arruda, aí morreu, ficou ainda aí. Assim, até no meu tempo, mas daí não tô lembrado como foi que acabou já, pessoal voltou pra cá também. Assim! Vendeu, cara, vendeu já, vendeu para outro já. Aí ainda falou não sei para quem, rapaz, eu não sei nem pra que tuxaua ele falou, se precisasse dele, ele estava aí pra dar uma força, o Bixara, né, mas quando vendeu, vendeu pro Bamerindus.

Após vender a área da fazenda para o banco Bamerindus, Bixara ainda ofereceu ajuda para os tuxauas dizendo que se as lideranças precisassem dele para aradar as roças, era só comunicá-lo, que ele cederia seus tratores para a comunidade. Os tuxauas, por sua vez, quando se atentaram para a situação, suas terras antigas já tinham sido vendidas para o banco Bamerindus. Bixara nunca devolveu a terra. Ele a registrou em seu nome e vendeu para o banco. $\mathrm{O}$ banco Bamerindus veio à falência em 1997.

Não encontrei tantas notícias sobre esse momento em que ocorreu a falência do banco e como ocorreu esse processo da passagem dessa terra para União, apenas que após a sua falência a terra se tornou devoluta, e foi nesse momento que as lideranças começaram a discutir a ampliação da Terra Indígena Serra da Moça nas reuniões a retomada de seus territórios.

Conforme a tia Gercina, quem teve a ideia, a princípio, de ampliação foi Jairo, juntamente com outras lideranças, como Leôncio Lourenço, Augusto da Silva Maruai, Jaime Pereira (pai do Jairo), Gecivaldo Aleixo Ângelo, Jackson Ângelo Aleixo, Marcelo Ângelo Aleixo, o próprio tio Assis Aleixo Ângelo, Nazário da Silva Ângelo, tia Gercina da Silva Ângelo, Anízio Bernadino Duarte, da Serra da Moça, entre outros que estiveram à frente da mobilização, já em 2004.

Isso nos revela que os contextos de relações interétnicas podem ter possibilitado o surgimento de uma consciência crítica de que era necessário retomar as terras que tinham ficado de fora da terra indígena demarcada. Jairo e as outras lideranças mencionadas nunca haviam se conformado com o minúsculo pedaço de terra. Conforme trabalhava para os fazendeiros, sempre questionava o porquê de ele estar trabalhando em território indígena, mas não 
poder usufruir dele de fato. Quando ia trabalhar nas fazendas, sempre avistava os lagos, igarapés, matos, e lembrava que em sua comunidade Morcego ${ }^{15}$ não tinha nada disso, o que o levava a não se conformar com esses limites. A partir disso, podemos supor que essa experiência relacionada à forma de mobilização de outras comunidades, especificamente na Terra Indígena Raposa/Serra do Sol, passou a inspirar as representações indígenas, como o CIR, juntamente com outras lideranças, como no caso do tuxaua Leôncio Lourenço, da Serra do Truarú, para reivindicar a ampliação da terra.

Nas assembleias regionais da etnorregião Taiano, sempre foi levada pelas lideranças que mencionei a necessidade de ampliar a Terra Indígena Serra da Moça, já que sua demarcação, ocorrida em 1991, não correspondia ao que as comunidades reivindicavam como territórios indígenas. Ficou de fora toda a terra que estava nas mãos dos fazendeiros, ficaram de fora os lagos, os igarapés e, o mais importante, parte do rio Uraricoera, a principal fonte de peixe e de caça.

No entanto, de acordo com as lideranças e confirmado pela assessora jurídica do CIR, Joênia Wapichana, no ano de 2016, apenas em 1997 é que foi protocolado o primeiro documento formal realizando o pedido de ampliação da terra. Esse documento foi uma carta da assembleia regional do Taiano, onde se contava a situação dos Wapichana e Macuxi da Terra Indígena Serra da Moça, afirmando que seus recursos naturais básicos, necessários para sua sobrevivência, eram escassos, e necessitavam ter acessos aos rios para caçar e pescar, já que eles eram impedidos constantemente pelos fazendeiros.

A carta primeiramente foi encaminhada ao CIR, que, por sua vez, a incluiu em suas pautas de defesa, de forma que pudesse acompanhar todo processo no âmbito administrativo e judiciário, como estar encaminhado a carta aos outros órgãos responsáveis pela demarcação de terras indígenas, como Funai, Ministério Público e Incra.

15 A comunidade Morcego, também da Terra Indígena Serra da Moça, foi a comunidade mais afetada pela relação com os fazendeiros locais que utilizavam mão de obra indígena. No relatório de identificação da terra consta que esses indígenas em especial sofriam maior pressão de fazendeiros, e que estavam numa relação de total subordinação, a ponto de serem obrigados a venderem sua força de trabalho devido à sua minúscula extensão territorial, o que tornava a caça, a pesca e a plantação de roças impossível (Melo, 2019, p. 28-29). 
Após anos sem resposta dessas instituições, os tuxauas continuaram se reunindo em assembleias e reuniões e essa pauta nunca foi esquecida. Mas, como ainda era possível ir caçar e pescar às escondidas, principalmente à noite, quando era menos arriscado ser pego pelos fazendeiros e seus capangas, por ora o pedido de ampliação era feito apenas nas assembleias estaduais, enviando documentos às organizações e órgãos competentes.

\section{Algumas experiências de lideranças}

Durante esse período, desde o primeiro pedido formal até 2004, quando houve de fato a ocupação da terra, as lideranças indígenas da Serra do Truarú participaram de diversos atos políticos em apoio à demarcação da Terra Indígena Raposa/Serra do Sol e de outras manifestações, tanto estaduais como nacionais. Como, por exemplo, o tuxaua Leôncio Lourenço e sua companheira Gercina da Silva Ângelo, que foram uma das famílias que moravam na Serra do Truarú e foram morar no Lago da Praia em 2004: eles estiveram presentes ativamente em diversos atos, reuniões, assembleias e encontros, e ocuparam diversos cargos no movimento indígena.

O tuxaua Leôncio Lourenço, por exemplo, atua no movimento indígena desde a década de 1970, como ele mesmo informou certo dia de setembro de 2018, ${ }^{16}$ quando fui visitá-lo para conversar sobre a situação do Lago da Praia. Leôncio fez questão de falar que lutou pela demarcação da Terra Indígena Serra da Moça, ao lado de seu amigo Francisco Rodrigues, mais conhecido como Chicão, que naquele período da pesquisa se encontrava enfermo e algumas semanas depois veio a falecer. Desde aquele tempo, ele já enfrentava algumas situações de conflito com fazendeiros; como ele mesmo contou, quando lutava para demarcar a terra em 1980, sua casa e a de Chicão foram queimadas pelos capangas dos fazendeiros e, depois, quando foi morar no Lago da Praia, lutando novamente para ampliar a terra, teve outra vez sua casa queimada. Nesse tempo, na década de 1980, casou-se com tia Gercina, que é moradora da Serra do Truarú, onde fez sua morada, já que ele nasceu na comunidade Serra

16 Entrevista com Leôncio Lourenço da Silva, Wapichana, morador da comunidade Serra do Truarú. Serra do Truarú, etnorregião Murupú, Município de Boa Vista. Setembro de 2018. 
da Moça e passou grande parte de sua juventude trabalhando como vaqueiro para os fazendeiros. Chicão e Leôncio iam em diversos órgãos falar com juízes, advogados, representantes do movimento indígena. Saíam de bicicleta até a cidade para levar a demanda da comunidade, embora naquela época ele não fosse tuxaua e sua atuação era muito mais por uma vontade pessoal do que por ser um representante eleito pela comunidade.

Quando fui conversar com Leôncio, pedi que ele contasse um pouco sobre sua vida. Enquanto estava debulhando feijão, Leôncio contou que nasceu na Serra da Moça, em 1959, e logo após, devido à separação de seus pais, foi morar com sua avó. Sua avó casou-se com um fazendeiro e, por isso, Leôncio viveu até os 16 anos de idade nas fazendas. Em 13 de setembro de 1973, resolveu voltar para a Serra da Moça e, daí, logo após, casou-se com tia Gercina, passando a morar na Serra do Truarú, próximo da residência de sua sogra.

Depois de ter essa experiência no "mundo dos fazendeiros" e ter voltado para sua comunidade, passou a atuar no movimento indígena. E em 1991, foi escolhido para ser liderança da comunidade; como ele mesmo disse, naquela época era uma pessoa muito inexperiente, mas mesmo assim aceitou o cargo. O primeiro cargo que ocupou foi o de vaqueiro, para cuidar do gado bovino comunitário, no dia $1^{\circ}$ de janeiro de 1991, e logo após, no dia 5 do mesmo mês, passou a ser liderança.

A partir daí, sua vida passou a ser voltada para o movimento indígena, e logo após ser eleito foi participar de uma assembleia geral do CIR na etnorregião Surumú. Leôncio conta que teve apoio de muitas pessoas que o ajudaram a entender o movimento indígena, como professores da comunidade, e, principalmente, contou com a experiência de outras lideranças que já atuavam há mais tempo. Todos os anos participava das assembleias gerais do CIR, viajava constantemente para eventos nacionais. Contou ainda que chegou a conhecer um pouco do Brasil, como as cidades de Manaus, Porto Seguro (BA), Belém, Brasília, Salvador. No ano 2000, chegou a participar da "Marcha dos 500 anos" que ocorreu na Bahia, onde se reuniram diversos povos indígenas para protestar contra a ideia de "descobrimento do Brasil" e reivindicar seus direitos.

Leôncio fala que, nesse período, a principal pauta levada pelos indígenas de Roraima era a luta pela demarcação da Terra Indígena Raposa/Serra do Sol e a ampliação das terras indígenas demarcadas em ilhas: "Nossa caravana era de 78 pessoas, daqui de Roraima, e fomos participar juntos de outros povos do 
Brasil. Então nós lutávamos por isso, né, lutava por essa área da Raposa/Serra do Sol e lutando pelas áreas em ilhas também."

Em setembro de 2018, quando conversei com Leôncio, ele tinha acabado de sair do cargo de tuxaua, depois de 25 anos ocupando cargo de liderança, seja de tuxaua ou também de coordenador regional, já que na época em que a Terra Indígena Serra da Moça fazia parte da etnorregião Taiano, chegou a ser um dos coordenadores; nesse período, teve que acompanhar diversos outros conflitos territoriais, como da comunidade Barata, localizada no município de Alto Alegre, que também reivindicava sua ampliação e a retirada de fazendeiros. Nesse caso, a luta obteve o resultado esperado, pois a comunidade conseguiu a ampliação.

Em 2004, se mudou da Serra do Truarú e foi morar na comunidade Lago da Praia, onde lutou novamente pela ampliação da terra. No entanto, no auge do conflito, teve sua casa queimada e teve que retornar para sua morada anterior, ocupando novamente cargos de tuxaua, coordenador regional do Murupú.

Tia Gercina, casada com Leôncio, também estava presente quando fui à sua casa, e o tempo todo ela complementava a fala do seu esposo, já que ela era quem o acompanhava nas reuniões e quem sabia de sua história, talvez até mais que ele, já que ela corrigia as datas o tempo todo. Como eu tinha ido pela manhã na casa deles e a conversa durou mais de uma hora, quando terminei a conversa com Leôncio, já era meio-dia e a bateria da câmera já estava descarregada. Tive que marcar para a parte da tarde a conversa com tia Gercina, e retornei à sua casa no mesmo dia.

Após retornar à sua casa, nos sentamos debaixo de uma mangueira, onde seu esposo Leôncio balançava na rede, observando um outro parente "batendo" arroz. ${ }^{17}$ Pedi também que ela iniciasse contando sua história e nos lembramos que, em abril de 2016, eu já tinha conversado com ela sobre o Lago da Praia. Só que, dessa vez, eu informei que queria ouvir um pouco de sua vida de liderança mulher indígena.

Então ela começou se apresentando novamente, como da primeira vez, falando que era do povo Wapichana, moradora da Serra do Truarú, e que começou sua vida de liderança no movimento indígena aos 12 anos como catequista

17 Bater arroz é o processo no qual a pessoa fica batendo os grãos de arroz ainda nos feixes para que eles se soltem, e, posteriormente, sejam descascados para o consumo. 
da Igreja Católica. ${ }^{18}$ Nesse tempo, ela já tinha tido acesso à educação formal, isto é, à escola dos não indígenas, onde aprendeu a ler e escrever.

Aprender a ler e escrever tornou-se um elemento muito importante para que um homem ou uma mulher indígena compreendesse o funcionamento das organizações indígenas e da sociedade nacional, como afirma Ortolan Matos (1997). As trajetórias das lideranças indígenas começavam muitas das vezes através dos estudos nas escolas, podendo ser uma escola da própria comunidade ou uma escola rural. No caso da tia Gercina, ela estudou em escolas localizadas nas proximidades da comunidade, que eram dirigidas pelo governo estadual. Essas novas habilidades combinadas com os discursos religiosos da Igreja Católica foram as primeiras experiências que ela teve e que podemos atribuir como essenciais para sua trajetória de liderança no movimento indígena. Sua atuação como catequista começou também nas igrejas que não eram da comunidade. Na década de 1980, quando foi implantada uma igreja católica na comunidade, tia Gercina começou também a participar, junto de sua amiga Margarete, da comunidade do Morcego, dos cursos de formação religiosa e política promovidos pelos missionários da Ordem da Consolata na etnorregião Taiano, onde participavam catequistas de várias comunidades. Além da formação religiosa para atuar como catequista, o momento era também uma oportunidade para compartilharem experiências de suas comunidades e suas situações de opressão:

Tia Gercina: Se falava muito, não tanto da palavra de Deus, mas como se vivia na comunidade, o que que a gente vivia, o que que a gente passava. Aí lá era igual a assembleia, cada comunidade tinha um catequista. Eles vinham também, levavam notícias das suas comunidades, como que a comunidade passava, o que estavam passando. Naquela época já tinha muito movimento que discutia a bebida alcoólica. E aí eu levava daqui também, né, como é que nós passávamos, o povo daqui. Aí eu conheci esse movimento. [...]

Ser catequista, naquele período, significava também fazer parte do movimento indígena, ou seja, eram funções que se combinavam devido à formação de catequistas promovida pela Igreja Católica, especificamente pela Ordem da

18 Entrevista com Gercina Ângelo da Silva, Wapichana, moradora da comunidade Serra do Truarú. Serra do Truarú, etnorregião Murupú, Município de Boa Vista. Setembro de 2018. 
Consolata, que atuava em Roraima, a partir de um viés político pautado na Teologia da Libertação, e que lutava ativamente pela causa dos indígenas. ${ }^{19}$

Aos 16 anos, a vida de catequista e, consequentemente, no movimento indígena da tia Gercina foi interrompida devido a uma doença grave, que a fez passar por uma cirurgia para a retirada de um cisto no ovário. A partir daí se manteve afastada por cerca de três anos, embora ela sempre estivesse informada acerca dos assuntos que eram discutidos: "Eu ouvia falando em demarcação de terra, que a gente devia valorizar a terra, tinha que nos fortalecer."

Aos 19 anos, depois que passou pela cirurgia, ela retornou para ser catequista, quando já estava casada com Leôncio e, assim, começou a "acompanhá-lo" nas reuniões do movimento indígena. Embora tenha usado o verbo "acompanhar" para ilustrar sua participação junto ao seu esposo, essa não é a palavra mais adequada, porque no mesmo período em que Leôncio tornou-se coordenador regional do Taiano, tia Gercina foi eleita para ser vice-coordenadora regional das mulheres representando a etnorregião Taiano, iniciando, assim, sua luta voltada especificamente para o movimento das mulheres indígenas de Roraima. Sua principal função era acompanhar a discussão do movimento indígena, no qual se discutiam as pautas mais amplas, ao mesmo tempo que estava acompanhando o surgimento da organização das mulheres, que pouco tempo depois, tornou-se Organização das Mulheres Indígenas de Roraima (Omirr) em 1999.

Quando as comunidades da Terra Indígena Serra da Moça passaram a compor a etnorregião Murupú em 2008, tia Gercina, já morando no Lago da Praia, foi eleita novamente para ser representante das mulheres na primeira assembleia regional do Murupú, que foi realizada na comunidade Serra do Truarú, não mais como vice, mas como primeira coordenadora da Organização das Mulheres Indígenas de Roraima, ${ }^{20}$ passando assim dois anos no cargo. Nesse período, também já tinha deixado a vida de catequese, tornando-se evangélica, mas mesmo assim não deixou a vida política do movimento indígena. Nesse tempo, participou de diversas manifestações, assembleias, encontros. Quando

19 Vieira (2003) trata em sua tese com mais profundidade sobre a atuação dessa ordem religiosa junto ao movimento indígena e à atuação de diversos religiosos nas comunidades, como Dom Aldo Mongiano, que passaram a atuar a partir de uma crítica à relação de opressão entre fazendeiros e indígenas.

20 Era não só a coordenadora principal, mas a primeira eleita no Murupú. 
não estava ocupando nenhum cargo, ela ia como participante, "acompanhando" seu esposo. Em 2017, participou do Acampamento Terra Livre (ATL), levando como pauta do movimento indígena de Roraima a ampliação da Terra Indígena Serra da Moça e a recuperação da comunidade Lago da Praia.

A família da tia Gercina e do tuxaua Leôncio foi das últimas famílias a saírem do Lago da Praia. Só saíram de lá quando tiveram sua casa queimada, no auge do conflito. Tiveram a maior parte dos seus pertences queimados pelo fogo.

\section{O início da luta: "Nós vamos retomar nosso território"}

Analisada a trajetória dessas duas lideranças, tanto da tia Gercina quanto do tuxaua Leôncio Lourenço, podemos considerar que suas atuações no movimento indígena e nas demandas que eles trazem consigo foram definidas a partir de suas experiências em contextos diversos: fora da comunidade, tendo contato tanto com discursos e atuações de outras lideranças, que já lutavam há mais tempo pela reivindicação da demarcação de terras, quanto com discursos religiosos. Soma-se a isso também a contradição que vivenciaram em relação à posse da terra pelos fazendeiros, em que a terra era constantemente diminuída e usurpada. Dentro da comunidade, tiveram experiências relacionadas à atuação de catequese da Igreja Católica e também à situação da própria comunidade, onde viviam sempre enfrentando dificuldades quando iam caçar ou pescar. A terra estava cada vez menor para qualquer atividade de criação e de agricultura.

O contexto do conflito que envolvia os indígenas da Terra Indígena Raposa/ Serra do Sol, em que participavam lideranças de todo estado de Roraima, era constantemente divulgado pela mídia nos jornais, rádios e outros meios. Dessa forma, uma das notícias que era sempre divulgada era a de que a terra que os Wapichana e Macuxi da Terra Indígena Serra da Moça estavam reivindicando seria dada para os "desintrusados" da Raposa/Serra do Sol depois da demarcação. Por isso, como já se estava num momento em que todos esperavam a demarcação da referida terra indígena, os indígenas se adiantaram e começaram a discutir a ocupação.

Tio Assis: A gente já tava sabendo que a pressão tava chegando de a gente perder as terras, aí fomos pra ver se ganhava aquela área lá, porque lá era área indígena 
também, era comunidade que é, quer dizer, era mesmo Santa Rita, morava Joãozinho, tudo era da nossa família mesmo, eles moravam por lá.

Essas experiências resultaram numa organização política interna e, a partir dela, foi possível mobilizar o restante dos indígenas da comunidade Serra do Truarú. Depois de anos sem respostas da Funai, do Incra e demais órgãos responsáveis quanto à ampliação da terra, resolveram ocupar seus antigos territórios, enviando no mês de março de 2004 a seguinte carta ao CIR, comunicando que estavam indo recuperar suas terras:

Ofício $n^{\circ} 001 / 03 / 2004$

Ao senhor Jacir José de Souza - Coordenador Geral do CIR

Reunião na Serra do Truarú

Nós moradores da Comunidade acima citada, através de suas lideranças abaixo assinado, vimos respeitosamente a presença de V. senhoria, informar que decidimos ocupar as terras indígenas da antiga fazenda Bamerindus, construindo uma nova comunidade. Como é de vosso conhecimento, essas terras foram prometidas para nós pelo Incra no ano passado na pessoa do Senhor Lurenes. Devido à demora para resolver este caso, decidimos ocupar logo a nossa parte. Motivos: está havendo muita proibição de caça e pesca por parte dos posseiros, somos ameaçados e muitas vezes obrigados a nos desfazer das caças e peixes quando somos encontrados dentro das terras. Informamos também que irá 10 famílias para construir 10 casas, 1 malocão, uma escola e um posto de saúde local às margens do rio Uraricoera. Contamos com seu apoio e necessitamos de transporte para conduzir as famílias e as pessoas que irão ajudar no trabalho e também para transportar palha e madeira para as construções. E na oportunidade, pedimos sua presença para participar de uma reunião na comunidade Serra do Truarú no dia 7 de abril de 2004, onde será tratado os últimos detalhes dessa ocupação e sua presença é importante, pois precisamos de alguns esclarecimentos.

Na manhã do dia 18 de abril de 2004, numa manhã ensolarada, subimos em um trator barulhento e saímos do centro comunitário da Serra do Truarú rumo às nossas antigas terras. $\mathrm{E}$, assim, estávamos iniciando uma nova comunidade: a comunidade Lago da Praia. 


\section{Considerações finais}

Este artigo objetivou descrever a mobilização para reocupar o território que, posteriormente, veio a constituir uma nova comunidade denominada Lago da Praia, construída por Wapichana e Macuxi da Terra Indígena Serra da Moça numa área que tinha sido usurpada por fazendeiros regionais e deixada de fora da demarcação em 1991. A partir dessas descrições, observamos que fatores como a trajetória das lideranças no movimento indígena, as privações que eram impostas às suas comunidades, como a negação de acesso aos rios e matas onde caçavam e pescavam e as condições desfavoráveis de trabalho, foram motores que colaboraram para o surgimento de uma consciência crítica sobre suas condições e sobre a situação de suas terras.

Ao trazermos esse caso como movimento que aciona fundamentos étnicos para atuar nos contextos de conflitos, percebemos uma interação simétrica e dialética, tanto com o fator econômico quanto com o político, que desencadeiam em forças capazes de transformar a realidade dos povos indígenas. Dessa forma, além do caso aqui apresentado, como outros que mencionei como exemplos de mobilizações sociais pautadas na identidade indígena, observamos que elas operam de uma maneira que é possível trazer para cada luta a especificidade cultural de cada povo, mesmo que essas lutas se assemelhem.

Assim, o que trago de contribuição, além de colocar essas comunidades no campo de discussões sobre retomadas territoriais, é ainda contribuir com o pensamento de que os fatores da identidade indígena não são apenas meros reflexos de alguns determinismos, mas representam elementos que funcionam como a própria resistência indígena capaz de mudar a situação de opressão em que vivemos.

Por fim, acredito que este trabalho pode ser um importante passo inicial para futuras discussões referentes ao campo tratado, já que neste momento me limitei apenas em etnografar os antecedentes da mobilização e os movimentos iniciais da retomada, porém o caso apresentado permanece em andamento nas instâncias da Justiça Federal, daí a necessidade de outros trabalhos para análise da retomada territorial de fato e os processos judiciários que tramitaram até a expulsão dos parentes da comunidade Lago da Praia. 


\section{Referências}

ALMEIDA, A. W. B. de. Terras tradicionalmente ocupadas: terra de quilombo, terras indígenas, "babaçuais livres", "castanhais do povo". Manaus: PPGSCA/UFAM, 2008.

ALMEIDA, A. W. B. de. Prólogo: um rio dividido?. In: ALMEIDA, A. W. B.; FARIAS JUNIOR, E. A. (org.). Mobilizações étnicas e transformações sociais no Rio Negro. Manaus: UEA Edições, 2010.

ALMEIDA, A. W. B. de. Questões agrárias no Maranhão contemporâneo. Manaus: UEA Edições, 2017.

ALMEIDA, A. W. B. de et al. (org.). Consulta e participação: a crítica à metáfora da teia de aranha. Manaus: UEA Edições, 2013.

BACHELARD, G. A formação do espírito científico: contribuição para uma psicanálise do conhecimento. Tradução Estela dos Santos Abreu. Rio de Janeiro: Contraponto, 2008.

BANIWA, G. S. L. Educação para manejo e domesticação do mundo: entre a escola ideal e a escola real. Os dilemas da educação escolar indígena no Alto Rio Negro. 2011. Tese (Doutorado em Antropologia Social) - Universidade de Brasília, Brasília, 2011.

BARTH, F. Os grupos étnicos e suas fronteiras. In: BARTH, F. O guru, o iniciador e outras variações antropológicas. Tradução de John Cunha Comeford. Rio de Janeiro: Contra Capa, 2000.

BENITES, T. Rojeroky hina ha roike jevy tekohape (Rezando e lutando): o movimento histórico do Aty Guasu dos Ava Kaiowa e dos Ava Guarani pela recuperação de seus tekoha. 2014. Tese (Doutorado em Antropologia Social) - Museu Nacional, Universidade Federal do Rio de Janeiro, Rio de Janeiro, 2014.

BOURDIEU, P. O poder simbólico. Rio de Janeiro: Bertrand Brasil, 2002.

BOURGOIS, P. Conjugated opression: class and ethnicity among Guaymi and Kuna Banana Workers. American Ethnologist, v. 15, n. 2, p. 328-348, 1988.

BOURGOIS, P. Ethnicity at work: divided labor on a Central American Banana plantation. Baltimore: Johns Hopkins University Press, 1989. 
BOURGOIS, P. La mobilisation ethinique. Actes de la Recherche en Sciences Sociales, n. 99, p. 53-64, 1993.

BOURGOIS, P. Banano, etnia y lucha en Centro América. San José: Editorial Departamento Ecuménico de Investigaciones (DEI), 1994.

BRASIL. Lei $n^{\circ}$ 6.001, de 19 de dezembro de 1973. Dispõe sobre o Estatuto do Índio. Brasília, 1973. Disponível em: http://www.planalto.gov.br/ccivil_03/Leis/L6001.htm. Acesso em: 15 set. 2019.

BRASIL. Decreto $n^{\circ} 258$, de 29 de outubro de 1991. Homologa a demarcação administrativa da área indígena Serra da Moça, no Estado de Roraima. Brasília, 1991. Disponível em: http://www.planalto.gov.br/ccivil_03/decreto/1990-1994/D258.htm. Acesso em: 15 set. 2019.

BRASIL. Decreto de 15 de abril de 2005. Homologa a demarcação administrativa da Terra Indígena Raposa Serra do Sol, localizada nos Municípios de Normandia, Pacaraima e Uiramutã, no Estado de Roraima. Brasília, 2005. Disponível em: http://www.planalto. gov.br/ccivil_03/_Ato2004-2006/2005/Dnn/Dnn10495.htm. Acesso em: 15 set. 2019.

CONSELHO INDÍGENA DE RORAIMA. Plano de gestão territorial e ambiental - Terra Indígena Serra da Moça. Boa Vista, [s.d.].

ELIAS, N. O processo civilizador: uma história dos costumes. 2. ed. Rio de Janeiro: Zahar, 2011.

FAVRET-SAADA, J. Ser afetado. Cadernos de Campo, São Paulo, v. 13. n. 13, p. 155-161, 2005.

KOKAMA, A. C. R. O reordenamento político e cultural do povo Kokama: a reconquista da língua e do território entre o Brasil e o Peru. 2016. Tese (Doutorado em Linguística) - Universidade de Brasília, Brasília, 2016.

MACUXI, I. B. S. Violência contra mulheres indígenas Macuxi: de experiências narradas a soluções coletivas. 2017. Dissertação (Mestrado em Antropologia Social) - Universidade Federal do Amazonas, Manaus, 2017.

MELO, E. A. de. Situação social, dinâmica territorial e mobilização étnica na Comunidade Serra do Truarú (Terra Indígena Serra da Moça, Etnorregião Murupú, Boa Vista-RR). 2019. Dissertação (Mestrado em Antropologia Social) - Universidade Federal do Amazonas, Manaus, 2019. 
MENEZES, E. S. Identidades coletivas e conflitos sociais: os piaçabeiros no médio rio Negro. 2012. Dissertação (Mestrado em Antropologia Social) - Universidade Federal do Amazonas, Manaus, 2012.

MENEZES, E. S. O trabalho extrativista da piaçaba em Barcelos AM, Brasil: servidão por dívida e resistência dos piaçabeiros. Revista Latinoamericana de Antropología del Trabajo, México, ano 3, n. 1, p. 1-20, 2018.

MENEZES, E. S. Identidade coletiva em disputa: a categoria de autodefinição "piaçabeiro" entendida a partir de suas narrativas. Wamon: Revista do Programa de Pós-Graduação em Antropologia Social da Universidade Federal do Amazonas, Manaus, v. 4, n. 1, p. 85-102, 2019.

NOVA CARTOGRAFIA SOCIAL DA AMAZÔNIA: Boletim Informativo: Projeto Mapeamento Social como Instrumento de Gestão Territorial contra o desmatamento e a devastação, Manaus, n. 5, jul. 2014.

ORTOLAN MATOS, M. H. O processo de criação e consolidação do movimento pan indígena no Brasil (1970-1980). 1997. Dissertação (Mestrado em Antropologia Social) Universidade de Brasília, Brasília, 1997.

ORTOLAN MATOS, M. H. Rumos do movimento indígena no Brasil contemporâneo: experiências exemplares no Vale do Javari. 2006. Tese (Doutorado em Ciências Sociais) - Instituto de Filosofia e Ciências Humanas, Universidade Estadual de Campinas, Campinas, 2006.

PACHECO DE OLIVEIRA, J. "O nosso governo": os Ticuna e o regime tutelar. São Paulo: Marco Zero, 1988.

PACHECO DE OLIVEIRA, J. O nascimento do Brasil e outros ensaios: pacificação, regime tutelar e formação de alteridades. Rio de Janeiro: Contra Capa, 2016.

SANTOS, G. S. Identidade étnica: os Sateré-Mawé no bairro da Redenção, em Manaus-AM. Dissertação (Mestrado em Sociedade e Cultura na Amazônia) - Universidade Federal do Amazonas, Manaus, 2008.

TERENA, L. H. E. A. Vukapanavo: o despertar do povo Terena para os seus direitos movimento indígena e confronto político. 2019. Tese (Doutorado em Antropologia Social) - Museu Nacional, Universidade Federal do Rio de Janeiro, Rio de Janeiro, 2019. 
TUXÁ, F. S. M. C. “Quando a terra sair”: os índios Tuxá de Rodelas e a barragem de Itaparica: memórias do desterro, memórias da resistência. 2017. Dissertação (Mestrado em Antropologia Social) - Universidade de Brasília, Brasília, 2017.

TUXÁ, F. S. M. C. Entre índios e sertanejos: o povo indígena Tuxá e a retórica desenvolvimentista chesfiana em Itaparica. Wamon: Revista dos alunos do Programa de Pós-Graduação em Antropologia Social da Universidade Federal do Amazonas, v. 3, n. 1, p. 39-53, 2018.

VIEIRA, J. G. Missionários, fazendeiros e índios em Roraima: a disputa pela terra - 1777 a 1980. 2003. Tese (Doutorado em História) - Universidade Federal de Pernambuco, Recife, 2003.

Recebido: 19/09/2019 Aceito: 27/04/2020 | Received: 9/19/2019 Accepted:4/27/2020 